\title{
IN VITRO ANTIOXIDANT ACTIVITY OF PHYLLODIUM PULCHELLUM L. DESV - AN THREATENED MEDICINAL PLANT
}

\section{GOPAL VELMURUGAN*, SUBRAMANIAM PARVATHI ANAND}

Department of Botany, National College (Autonomous), Tiruchirappalli - 620 001, Tamil Nadu, India. Email: velmuruganbotany@gmail.com Received: 13 May 2016, Revised and Accepted: 30 June 2017

ABSTRACT

Objectives: In this study, we determined the in vitro antioxidant capacity of Phyllodium pulchellum of aqueous, ethanol, and chloroform leaf extracts.

Methods: In this context, the in vitro antioxidant activity was demonstrated by 2,2-diphenyl-1-picrylhydrazyl (DPPH), 2,2'-azinobis(3ethylbenzothiazolone-6-sulfonic acid) (ABTS+) radical scavenging assay, the total antioxidant activity of phosphomolybdenum assay and hydroxyl radical scavenging activity in different leaf extracts of $P$. pulchellum. The antioxidant activity of the extracts was compared to standard ascorbic acid.

Results: All the four methods of antioxidant showed good reducing power and reducing capacity with increasing concentration again taking the ethanol leaf extract to the top position. Remarkable of antioxidant activity was observed in ethanol leaf extract on the hydrogen peroxide scavenging activity with the lowest inhibitory concentration 50 values of $(155.40 \mu \mathrm{g} / \mathrm{ml})$ followed by DPPH $(432.90 \mu \mathrm{g} / \mathrm{ml}) \mathrm{and} \mathrm{ABTS}+(524.40 \mu \mathrm{g} / \mathrm{ml})$.

Conclusion: These results suggest that the leaf of $P$. pulchellum could be a valuable source of new antioxidant properties, from the above results it seen that this plant exhibits pharmaceutical activity.

Keywords: Phyllodium pulchellum, Fabaceae, Leaf extracts, 2,2-diphenyl-1-picrylhydrazyl, 2,2'-azinobis(3-ethylbenzothiazolone-6-sulfonic acid), Inhibitory concentration 50 .

(C) 2017 The Authors. Published by Innovare Academic Sciences Pvt Ltd. This is an open access article under the CC BY license (http://creativecommons. org/licenses/by/4. 0/) DOI: http://dx.doi.org/10.22159/ajpcr.2017.v10i10.19919

\section{INTRODUCTION}

Phyllodium pulchellum L. Desv. (Vellalothi in Tamil) is a flowering plant species and widely distributed in South India as a threatened medicinal plant belonging to the family of Fabaceae. It is a Subshrub 1(3) m; branchlets downy pubescent to tomentose. P. pulchellum (Syn. Desmodium pulchellum (L.) Benth) is used to treat various diseases such as anti-inflammatory, analgesic, antioxidant, hemorrhage, diarrhea, poisoning, and eye diseases [1]. The genus relative plants are reported to have anthelmintic [2], anti-hepatic fibrotic [3], antidiarrheal [4], anti-inflammatory [5], and antidiabetic [6]. The international union for conservation of natural and national resource has a long time ago listed P. pulchellum (L.) Desv. as a threatened species [7]. The genus Desmodium, of the Fabaceae family, includes about 350 species distributed in tropical and subtropical zones of the worldwide. However, no studies to date have been able to reveal the antioxidant effect of any Desmodium species other than D. gangeticum and D. triflorum. Hence, for there is no scientific report on the antioxidant activities in the particular species. Therefore, the present study was undertaken to evaluate and compare the antioxidative activities of different solvent leaf extracts of $P$. pulchellum in different methods.

\section{MATERIALS AND METHODS}

\section{Plant material}

P. pulchellum was collected from the Jambhudu hamlet of Bodamalai at Namakkal District, Tamil Nadu, India, and identified following the Botanical Survey of India and the voucher specimen (BSI/SRC/5/23/2012-13/Tech-1795 \& Serial No. 2) was deposited in the herbarium ofthe DepartmentofBotany,National College(Autonomous), Tiruchirappalli - 620 001, Tamil Nadu, India.

\section{Preparation of plant extracts}

Fresh plant material was washed under running tap water, air dried and powdered. About $30 \mathrm{~g}$ of coarsely powdered plant materials
(30 g/300 ml) were extracted in a Soxhlet extractor for 8-10 hrs, sequentially with aqueous, ethanol, and chloroform. All the solvent extracts were evaporated to remove the final traces of the respective solvents. Dried extracts were kept at $20^{\circ} \mathrm{C}$ until further test was carried out.

\section{In vitro antioxidant activity}

Free radical scavenging activity of the various solvent of leaf extracts in $P$. pulchellum was determined using various in vitro assays such as 2,2-diphenyl-1-picrylhydrazyl (DPPH) radical scavenging activity, 2,2'-azinobis(3-ethylbenzothiazolone-6-sulfonic acid) (ABTS) radical scavenging assay, total antioxidant activity of phosphomolybdenum assay, and hydroxyl radical scavenging activity.

\section{DPPH radical scavenging activity}

Free radical scavenging activity was measured using DPPH method [8]. Different concentrations $(1000,800,600,400$, and $200 \mu \mathrm{g} / \mathrm{ml})$ of crude extracts and taken in test tubes in triplicates. Then, $5 \mathrm{ml}$ of a $0.1 \mathrm{mM}$ ethanol solution of DPPH (1,1,diphenyl-2-picrylhydrazyl) was added to each of the test tubes and was shaken vigorously. They were then allowed to stand at $37^{\circ} \mathrm{C}$ for 20 minutes. The control was prepared without any extracts. Ethanol was used for baseline corrections in absorbance (optical density [OD]) of the sample measured at $517 \mathrm{NM}$. Ascorbic acid is used as reference antioxidant compound. A radical scavenging activity was expressed as $1 \%$ scavenging activity and was calculated by the following formula:

$$
\text { Radical scavenging activity }(\%)=\frac{\text { OD control }- \text { OD sample }}{\text { OD control }} \times 100
$$

ABTS radical scavenging assay

The efficacy of plant extracts to scavenge free radicals was determined using ABTS radical scavenging assay with minor modification [9]. Freshly prepare the ABTS radical solution by adding $5 \mathrm{ml}$ of $4.9 \mathrm{mM}$ 
ammonium persulfate solution to $5 \mathrm{ml}$ of a $14 \mathrm{mM}$ ABTS solution and keep for 16 hrs under dark condition. The solution is diluted with distilled water to yield an absorbance of $0.70 \pm 0.02$ at $734 \mathrm{~nm}$, and the same is used for the assay. To $900 \mu \mathrm{l}$ of the ABTS radical solution, add $100 \mu \mathrm{l}$ of the extract $(1000,800,600,400$, and $200 \mu \mathrm{g} / \mathrm{ml})$ and the reaction mixture is vortexed for 10 seconds and the assay was done. 6 minutes after record the absorbance at $734 \mathrm{~nm}$ against distilled water using (Beckman DU-530) ultraviolet-visible spectrophotometer. Ascorbic acid was used as reference standard. The radical scavenging activity was calculated using the formula:

$$
\text { ABT scavenging activity }=\frac{\text { Absorbance of test sample }}{\text { Absorbance of blank sample }} \times 100
$$

\section{Total antioxidant activity of phosphomolybdenum assay}

Determination of total antioxidant capacity developed by method [10]. $0.2 \mathrm{ml}$ of plant extract $(1000,800,600,400$, and $200 \mu \mathrm{g} / \mathrm{ml})$ is mixed with $1.8 \mathrm{ml}$ of distilled water, $2 \mathrm{ml}$ of phosphomolybdenum reagent solution. Incubate it at $95^{\circ} \mathrm{C}$ for 90 minutes. The mixture is cooled to room temperature, and the absorbance is measured at $695 \mathrm{~nm}$ against a reagent blank. The test was performed in triplicate. The antioxidant capacity is expressed as ascorbic acid equivalent (AAE) and was calculated by the following theoretical formula:

$$
A=\frac{c \times V}{M}
$$

Where, $\mathrm{A}=$ Total content of antioxidant compounds, $(\mathrm{mg} / \mathrm{g})$ leaf extract, in AAE, $c=$ The concentration of ascorbic acid established from the calibration curve, $(\mathrm{mg} / \mathrm{ml}), \mathrm{V}=$ The volume of extract $(\mathrm{ml})$, and $\mathrm{m}=$ The weight of crude leaf extract (g).

\section{Hydroxyl radical scavenging activity}

The scavenging activity of the leaf extract on hydroxyl radical was measured according to the method [11]. Various concentrations (200, $400,600,800$, and $1000 \mu \mathrm{g} / \mathrm{ml}$ ) of extracts were added to $1.0 \mathrm{ml}$ of iron-ethylenediaminetetraacetate (EDTA) solution $(0.13 \%$ ferrous ammonium sulfate and $0.26 \%$ EDTA), $0.5 \mathrm{ml}$ of EDTA solution $(0.018 \%)$, and $1.0 \mathrm{ml}$ of dimethyl sulfoxide $(0.85 \% \mathrm{v} / \mathrm{v}$ in $0.1 \mathrm{M}$ phosphate buffer, $\mathrm{pH}$ 7.4). The reaction was initiated by adding $0.5 \mathrm{ml}$ of ascorbic acid $(0.22 \%)$ and incubated at $80-90^{\circ} \mathrm{C}$ for 15 minutes in a water bath. After incubation, the reaction was terminated by the addition of $1.0 \mathrm{ml}$ of ice-cold trichloroacetic acid $(17.5 \% \mathrm{w} / \mathrm{v}) .3 \mathrm{ml}$ of Nash reagent $(75.0 \mathrm{~g}$ of ammonium acetate, $3.0 \mathrm{ml}$ of glacial acetic acid, and $2 \mathrm{ml}$ of acetyl acetone were mixed and raised to $1 \mathrm{~L}$ with distilled water) were added and left at room temperature for 15 minutes, and the test was done 3 times. The reaction mixture without sample was used as a control. The intensity of the color formed was measured spectroscopically at $412 \mathrm{~nm}$ against the reagent blank. The percent hydroxyl radical scavenging activity is calculated by the following formula:

Hydroxyl radical scavenging activity $=\frac{\text { Test sample absorbance }}{\text { Blank sample absorbance }} \times 100$

\section{RESULTS AND DISCUSSION}

\section{DPPH radical scavenging activity}

The scavenging activity of all the extracts was found to be less when compared to that the standard ascorbic acid. Among the different extracts, the ethanol leaf extracts of showed high DPPH scavenging activity at $1000 \mu \mathrm{g} / \mathrm{ml}(81.5 \pm 0.02)$ followed by aqueous and chloroform (Table 1). From the results, it is known that the species, P. pulchellum possess hydrogen donating capabilities for ethanolic leaf extracts and execute scavenging free radicals.

\section{ABTS radical scavenging assay}

ABTS radical scavenging activity of different extracts of $P$. pulchellum is shown in Table 2. Ethanolic leaf extracts of $P$. pulchellum showed maximum free radical scavenging for ABTS assay at $1000 \mu \mathrm{g} / \mathrm{ml}$ concentration $(75.13 \%)$ with a respective standard value of $(82.13 \%)$ followed by aqueous and chloroform extracts. Among the all tested plant samples, ethanolic extracts of P. pulchellum exhibited the majority effective radical scavenging activity. All the extracts showed an increase in antioxidant capacity with an increase in the amount.

\section{Total antioxidant activity of phosphomolybdenum assay}

Phosphomolybdate method is also a quantitative assay, while the total antioxidant capacity is expressed as AAE. The total antioxidant activity of different concentrations in $(200-1000 \mu \mathrm{g} / \mathrm{ml})$ this method. The ethanolic leaf extract is higher than $(2.069 \pm 0.002)$ with in respective standard value is $2.201 \pm 0.029$. Although the antioxidant capacity of the extracts was found to the decrease arrange as followed by ethanol>aqueous>chloroform (Table 3).

\section{Hydroxyl radical scavenging activity}

The concentrations range from 200 to $1000 \mu \mathrm{g} / \mathrm{ml}$ of different extracts was assessed for their hydroxyl radical scavenging activity. From

Table 1: DPPH radical scavenging activity of leaf extract from P. pulchellum

\begin{tabular}{llll}
\hline Concentration $(\boldsymbol{\mu g} / \mathbf{m l})$ & \multicolumn{2}{l}{ Absorbance at $\mathbf{5 1 7} \mathbf{~ n m}$} & \\
\cline { 2 - 4 } & Aqueous extract & Ethanol extract & Chloroform extract \\
\hline 200 & $34.7 \pm 0.03$ & $37.7 \pm 0.05$ & $23.4 \pm 0.02$ \\
400 & $45.5 \pm 0.04$ & $48.2 \pm 0.02$ & $36.3 \pm 0.57$ \\
600 & $56.1 \pm 0.02$ & $58.6 \pm 0.04$ & $47.6 \pm 0.05$ \\
800 & $68.6 \pm 0.01$ & $69.3 \pm 0.03$ & $50.6 \pm 0.06$ \\
1000 & $76.8 \pm 0.03$ & $81.5 \pm 0.02$ & $67.2 \pm 0.10$ \\
\hline
\end{tabular}

Values were performed in triplicates and represented as mean \pm SD, DPPH: 2,2-diphenyl-1-picrylhydrazyl, P. pulchellum: Phyllodium pulchellum

Table 2: Activity of $P$. pulchellum leaf extracts in the ABTS cation radical assay

\begin{tabular}{llll}
\hline Concentration $(\boldsymbol{\mu g} / \mathbf{m l})$ & \multicolumn{2}{l}{$\%$ inhibition of ABTS radical } & Chloroform extract \\
\cline { 2 - 4 } & Aqueous extract & Ethanol extract & 19.11 \\
\hline 200 & 20.15 & 27.19 & 28.10 \\
400 & 33.70 & 44.13 & 41.01 \\
600 & 47.62 & 58.82 & 53.05 \\
800 & 59.31 & 67.31 & 68.82 \\
1000 & 72.41 & 75.13 & 42.87 \\
\hline
\end{tabular}

ABTS: 2,2'-azinobis (3-ethylbenzothiazolone-6-sulfonic acid), P. pulchellum: Phyllodium pulchellum 
Table 3: Total antioxidant activity of phosphomolybdenum assay

\begin{tabular}{|c|c|c|c|c|}
\hline \multirow[t]{2}{*}{ Concentration $(\mu \mathrm{g} / \mathrm{ml})$} & \multicolumn{4}{|c|}{ Absorbance at $695 \mathrm{~nm}$} \\
\hline & Aqueous extract & Ethanol extract & Chloroform extract & Ascorbic acid (SD) \\
\hline 200 & $1.258 \pm 0.008$ & $1.311 \pm 0.021$ & $1.125 \pm 0.012$ & $1.121 \pm 0.018$ \\
\hline 400 & $1.422 \pm 0.005$ & $1.572 \pm 0.011$ & $1.322 \pm 0.010$ & $1.346 \pm 0.024$ \\
\hline 600 & $1.629 \pm 0.006$ & $1.692 \pm 0.013$ & $1.492 \pm 0.023$ & $1.657 \pm 0.072$ \\
\hline 800 & $1.811 \pm 0.007$ & $1.881 \pm 0.005$ & $1.662 \pm 0.043$ & $1.824 \pm 0.043$ \\
\hline 1000 & $1.926 \pm 0.015$ & $2.069 \pm 0.002$ & $1.726 \pm 0.018$ & $2.201 \pm 0.029$ \\
\hline
\end{tabular}

Values were performed in triplicates and represented as mean $\pm \mathrm{SD}$

Table 4: Hydroxyl radical scavenging activity

\begin{tabular}{lllll}
\hline Concentration $(\boldsymbol{\mu g} / \mathbf{m l})$ & \multicolumn{4}{l}{ \% Inhibition of hydroxyl radical scavenging } \\
\cline { 2 - 5 } & Aqueous extract & Ethanol extract & Chloroform extract & Ascorbic acid (SD) \\
\hline 200 & 42.21 & 51.25 & 41.01 & 53.01 \\
400 & 54.11 & 63.32 & 53.43 & 66.13 \\
600 & 67.01 & 75.13 & 61.79 & 78.37 \\
800 & 78.13 & 84.27 & 73.11 & 86.18 \\
1000 & 84.51 & 93.70 & 81.15 & 96.67 \\
\hline
\end{tabular}

Table 5: $\mathrm{IC}_{50}$ values of P. pulchellum in radical scavenging assay

\begin{tabular}{llll}
\hline Leaf extract & $\begin{array}{l}\text { DPPH radical scavenging } \\
\text { activity }(\boldsymbol{\mu g} / \mathbf{m l})\end{array}$ & $\begin{array}{l}\text { ABTS radical inhibition } \\
\text { activity }(\boldsymbol{\mu g} / \mathbf{m l})\end{array}$ & $\begin{array}{l}\text { Hydroxyl radical scavenging } \\
\text { activity }(\boldsymbol{\mu g} / \mathbf{m l})\end{array}$ \\
\hline Aqueous extract & 481.37 & 651.32 & 320.29 \\
Ethanol extract & 432.90 & 524.40 & 155.40 \\
Chloroform extract & 698.42 & 728.18 & 357.80 \\
Ascorbic acid (SD) & 417.60 & 529.21 & 114.32 \\
\hline
\end{tabular}

DPPH: 2,2-diphenyl-1-picrylhydrazyl, ABTS: 2,2'-azinobis (3-ethylbenzothiazolone-6-sulfonic acid), IC ${ }_{50}$ : Inhibitory concentration 50

Table 4, it is clear that the ethanolic leaf extracts of P. pulchellum showed greatest scavenging activity $(93.70 \%)$ at $1000 \mu \mathrm{g} / \mathrm{ml}$ concentration followed by aqueous and chloroform with the standard values of $96.67 \%$, respectively. The results showed the scavenging potential of P. pulchellum against hydroxyl radicals (Table 4).

The dosage of the extract is expressed in $\mu \mathrm{g}$ of the dry weight of the extract (compound)/mL of the assay mixture. Inhibitory concentration $50\left(\mathrm{IC}_{50}\right)$ value represents the concentration of test extract or compound where the inhibition of test activity reached $50 \%$. Among the plant extracts, ethanolic extract showed the highest activity, with an $\mathrm{IC}_{50}$ value of $524.40 \mu \mathrm{g} / \mathrm{ml}$. Moreover, the ABTs radical inhibition activity was in the order ethanol>chloroform $>$ aqueous. The $\mathrm{IC}_{50}$ value of aqueous and chloroform extracts and ascorbic acid was $651.32 \mu \mathrm{g} / \mathrm{ml}, 728.18 \mu \mathrm{g} / \mathrm{ml}$, and $529.21 \mu \mathrm{g} / \mathrm{ml}$, respectively. The DPPH radical scavenging capacity in the order: Ethanol>chloroform>aqueous and then scavenging ability on hydroxyl radicals was in the order: Ethanol>chloroform>aqueous (Table 5).

Rising concern in the investigate for natural alternatives in favor of synthetic antioxidant has led to the evaluation of plant sources. In this study, leaf extract of $P$. pulchellum exhibited outstanding scavenging effects on DPPH radical scavenging activity, ABTS radical scavenging assay, total antioxidant activity of phosphomolybdenum assay, and hydroxyl radical scavengingactivity. Along with the good number widely used procedures for measurement of antioxidant activity capacity, the DPPH radical scavenging analysis is one of the top known, correct, and regularly employed to measure the electron donating ability of the plant $[12,13]$. Dechayont et al., reported that the moderate antioxidant activity from Pogostemon cablin and inhibited bacteria commonly responsible for community and hospital acquired infections [14]. Usmangani et al. reported that leaf and fruit extracts of D. palmatus were determined to have a certain level of radical scavenging effect, proportional to their level of phytochemicals [15]. Similar reported on antioxidant activity was Phyllodium genus relative synonymous species, Desmodium gangeticum (L.) DC., Desmodium heterocarpon (L.) DC., Desmodium intortum (DC.) Urb., Desmodium microphyllum (Thunb ex Murray) DC., Desmodium renifolium (L.) Schindl., Desmodium scorpiurus (Sw.) Desv., Desmodium sequax Wall. (DSE), Desmodium tortuosum (Sw.) DC., D. triflorum (L.) DC., and D. uncinatum DC.[16]. A similar observation was made in Toddalia asiatica [17], Thevetia peruviana [18], and Leucas aspera [19] reported that the amount of sensitivity increased with the regular increase in the concentration of extracts. There is no report that antioxidant activity of $P$. pulchellum leaf extracts. Hence, far we identify this is the first report that envisages the antioxidant activities of $P$. pulchellum leaf extracts. The extracts of P. pulchellum could be potential as a source of valuable phytochemical compounds used for the pharmaceutical industry and antioxidant mechanisms.

\section{CONCLUSION}

Based on the resulted find in this study, it is concluded that the ethanolic leaf extract of $P$. pulchellum exhibits considerable antioxidant radical scavenging activity on all tested assays. Therefore, further research is needed for the isolation and identification of the active components in the extracts.

\section{REFERENCES}

1. Velmurugan G, Anand SP, Doss A . Phyllodium pulchellum: A potential medicinal plant-A review. Int J Pharm Rev Res 2014;4(4):203-6.

2. Muckda C, Smarn T, Sasithorn K. Preliminary study, effects of Desmodium pulchellum root on Opisthorchis viverrini in hamsters. Srinagarind Med J 1989;4(3):190-4.

3. Yu S, Zhong M, Huang L. The effect of Desmodium pulchellum on the content of liver collagen protein of testing hepatic fibrosis rats. Hunan Guid J Tradit Chin Med Pharmacol 1999;27:8-32.

4. Khalilur R, Soumitra B, Fokhrul I, Rafikul I, Mohammed AS, Shahnaj P, et al. Studies on the anti-diarrheal properties of leaf extract of Desmodium pulchellum. Asian Pac J Trop Biomed 2013;3(8):639-43.

5. Noor SS, Rahman MA, Zebunnesa A, Atanu D, Monir H. Evaluation 
of anti-inflammatory and antidiabetic activity of ethanolic extracts of Desmodium pulchellum Benth. (Fabaceae) barks on Albino wistar rats. J Appl Pharm Sci 2013;3(7):48-51.

6. Jain SK. Dictionary of Indian Folk Medicine and Ethnobotany. New Delhi: Deep Publications; 1991

7. Poveda LL. Phyllodium pulchellum. The IUCN Red List of Threatened Species; 2012.

8. Blois MS. Antioxidant determinations by the use of stable free radical. Nature 1958;81:1199-2000.

9. Re R, Pellegrini N, Proteggente A, Pannala A, Yang M, Rice-Evans C. Antioxidant activity applying an improved ABTS radical cation decolorization assay. Free Radic Biol Med 1999;26(9-10):1231-7.

10. Prieto P, Pineda M, Aguilar M. Spectrophotometric quantitation of antioxidant capacity through the formation of a phosphomolybdenum complex: Specific application to the determination of Vitamin E. Anal Biochem 1999;269(2):337-41

11. Klein D, Moore RY, Reppert SM, editors. Supra Chiasmatic Nucleus: The Mind's Clock. Oxford: Oxford University Press; 1991.

12. Figueroa LA, Navarro LB, Vera MP, Petricevich VL. Antioxidant activity, total phenolic and flavonoid contents, and cytotoxicity evaluation of Bougainvillea xbuttiana. Int J Pharm Pharm Sci 2014;6(5):497-502.
13. Ahmad B, Khan MR, Shah NA, Khan RA. In vitro antioxidant potential of dicliptera roxburghiana. BMC Complement Altern Med 2013;13:140.

14. Dechayont B, Ruamdee P, Poonnaimuang S, Mokmued K, ChunthorngOrn J. Antioxidant and antimicrobial activities of Pogostemon cablin (Blanco) Benth. J Bot 2017;2017:1-6.

15. Attar UA, Ghane SG. Phytochemicals, antioxidant activity and phenolic profiling of Diplocyclos palmatus (1.) C. Jeffrey. Int J Pharm Pharm Sci 2017;9(4):101-6.

16. Tsai JC, Huang GJ, Chiu TH, Huang SS, Huang SC, Huang TH, et al. Antioxidant activities of phenolic components from various plants of Desmodium species. Afr J Pharm Pharmacol 2011;5:468-76.

17. Thangavelu K, Ravisankar N, Siddiq A, Joseph J. In vitro antioxidant and anticancer potential of flowers of Toddalia asiatica (Rutaceae). Int J Pharm Pharm Sci 2015;7(3):95-9.

18. Anupma D, Hemlata S, Sharma RA, Archana S. Estimation of antioxidant and antibacterial activity of crude extracts of Thevetia peruviana (Pers.) K. Schum. Int J Pharm Pharm Sci 2015;7(2):55-9.

19. Tahareen S, Shwetha R, Myrene RD. Potential antioxidant, antiinflammatory and antibacterial evaluation of extracts of Leucas aspera using in vitro models . Int J Pharm Pharm Sci 2016;8(12):292-7. 